as a small walnut, and was plainly discernible as a swelling at the upper and inner angle of the orbit, pressing down the lid over the eye, and causing a good deal of deformity; it extended some distance into the orbit. It was determined to treat the case by electrolysis. Treatment was accordingly commenced on May $12 \mathrm{th}$, when the needle was inserted three times; on the 26th and on July 3rd the process was repeated, the number of punctures being the same. At this latter date it was noted that the tumour was less than half its original size. After this it gradually dwindled, but the child, from ill-health, I believe, was only brought occasionally, and then not for active treatment. In 1883, the nævus was greatly reduced in size, and was hardened. On Jan. 22nd and Feb. 5th electrolysis was again resorted to, with the effect of dispersing the swelling. Later the mother came to inform me of the child's death from croup, and asserted that the tumour had quite disappeared.

$\mathrm{C}_{\triangle \mathrm{SE}} 2$ 2,-Beatrice $\mathrm{H}-$, aged nine months, was first seen in November, 1884. The mother had perceived, in the previous April, a little dark patch at the inner side of the right upper eyelid. At the time of the baby being brought to the infirmary, at the upper and inner angle of the orbit was a purplish swelling about the size of a bean; it only showed itself on the surface, but extended more deeply. The mother thought it had not increased much in size since it was first noticed. On Dec. 1st treatment with electrolysis was commenced, three punctures being made with five cells; on the 8 th and 15th, and also on Feb. 3rd, it was repeated. Soon after this last date it had disappeared.

CaSE 3.-Jane L. E-—, aged about three months, was brought to the infirmary in February, 1885. The nævus in this instance was larger than that in the last, but smaller than in the first-mentioned case. It was situated at the upper end and inner angle of the orbit, and extended deeply. The surface on the eyelid was purplish. The swelling became distended, as the others had done, on the child crying, and refilled after having been dispersed by pressure. It produced u good deal of deformity, and pressed the eyelid down over the eyeball at the inner side. The mother had noticed it only about a month before, and thought it had quickly increased in size. Exterior to it, at a little distance on the upper eyelid, was a small red-coloured cutaneous nævus. Treatment by electrolysis was commenced on Feb. 9th. Eight cells were employed and three punctures made; the superficial nævus was destroyed by the actual cautery. On the $23 \mathrm{rd}$ three punctures were made (ten cells); on April 20th, four punctures (twelve cells); on May 11th, four punctures (fifteen cells); and on June $1 \mathrm{~s}^{t}$, one puncture (fifteen cells), and three punctures (nine cells). The result was excellent.

CASES 4 \& 5.-Since writing the above two other cases have been under treatment. Both occurred in young babies. One nævus, the size of an almond, was situated at the inner angle of the orbit, more on the nose than the eyelid. Electrolysis was repeated four times, and it disappeared. The other was as large as a half-crown, and occupied the left lower eyelid at the outer part and the cheek over the malar region. It is disappearing under electrolysis.

From six to ten cells of the battery will generally suffice in Case 3 more were employed because the power of the instrument was deteriorating. A sufficient strength should be employed that will decompose water readily, and if this be tested before proceeding with the operation, it affords a simple plan of determining which needle to remove and which to keep stationary-the one from which the bubbles freely escape will be the one to use in the first manner.

Cambridge Medical Graduates' Club. - The annual meeting and dinner of this Club was held at Caius College, Cambridge, on Saturday last, the 17th inst., Sir George Paget, K.C.B., a Vice-President of the Club, in the chair. Among the guests present at the dinner were the several professors of those collateral branches of science most closely connected with the study of medicine-viz., Prof. Newton (Comparative Anatomy), Prof. MacAlister (Human Anatomy), Prof. Dewar (Natural Experimental Philosophy), and Prof. Roy (Pathology). The Fellows of Cauis College then in residence were also present as guests of the Club, together with Mr. T. Pridgin Teale of Leeds. The principal speakers were the Chairman, Prof. Humphry, Mr. Timothy Holmes, and Mr. Teale. It was announced during the evening that the Club was in a most prosperous condition, having now close upon two hundred members.

\section{THE INSUFFLATION OF IODOFORM INTO THE TRACHEA AFTER TRACHEOTOM'Y FOR DIPHTHERIA.}

BY GEORGE SHIRRES, M.B., C.M., LATE RESIDENT ASSISTANT SURGEON, ROYAL INFIRMARY, ABERDEEY.

WERE it not for the fact that after tracheotomy for diphtheria in children death is extremely common from the spread of the membrane down the trachea, the operation would be much more popular than it is at present. It is usually simple and successful enough as an operation, but the continuation of the disease in the trachea renders the final results far from satisfactory. After losing several cases from the above cause, it occurred to me that the insufflation of iodoform into the trachea after the opening of the windpipe might do something towards preventing the appearance of membrane there, and might thereby lessen the probability of death. The experiment proved eminently successful in the following two cases.

CASE 1.- I was called to see a boy aged four years and a half on the night of Nov. 2nd, 1885. I found the case to be typical of the so-called diphtheritic croup. The face was flushed, the glands beneath the angle of the jaw were enlarged, and his breathing was stridulous and performed with great effort. I advised instant tracheotomy, which the parents refused. I prescribed aconite, the use of the steam-kettle, \&c., and left him for the night, very doubtful of his chance of life. When I saw him next morning the symptoms were intensified. The face was livid, the eyes staring, and the expression one of extreme anxiety. The sternum and anterior parts of the chest wall were retracted during inspiration. I insisted upon tracheotomy being performed, to which the parents consented, but with reluctance. I left for instruments and assistance, and on my return found the child in the same condition. I placed the patient under chloroform and opened the trachea. A large quantity of blood and membrane were at once expectorated through the wound, and the tube was without much trouble placed in the trachea. After this artificial respiration had to be resorted to, and was continued by my colieague, Dr. Bridger, for fully twenty minutes before respiration was properly established. Two hours after the operation I removed the inner tube, passed a thin insufflator down the outer one, and blew about ten grains of iodoform down the trachea. The child had a slight paroxysm of coughing, and, to judge from the expression of his face, seemed to experience a rather unpleasant sensation, but there was no worse result. The insufflation was repeated every four hours. Next morning I found the tube comparatively clear, but the temperature was $1025^{\circ}$. Being rather afraid of iodoform poisoning 1 stopped the insufflation. During the day the tube got frequently clogged with membrane, and had to be removed and cleaned every two or three hours. At night I resimed the insufflation and repeated it every three hours, with excellent effect. At 3 o'clock next morning I was called by the patient's father, who, in attempting to remove the inner tube, had pulled the outer one with it. I found the patient in great distress, breathing through the wound with considerable effort. After some difficulty I reinserted the tube From that time the patient rapidly recovered, and on the fifth day I removed the tube. The patient is now alive and quite well, with a slight cicatrix over the site of the wound.

CASE 2.-This was a somewhat similar case to the foregoing, although the symptoms were not so well marked. The patient was a little girl three years of age, whom I was called to see on the night of Dec. 10th, 1885. I found the patient suffering from symptoms of suffocation. The breathing was stridulous, the voice scarcely audible, the glands beneath the angle of the jaw enlarged, and the face much flushed. I recommended tracheotomy, and performed the operation that night. After the tube was inserted, I insufflated about fifteen grains of iodoform into the trachea, and repeated this procedure every four hours. The child made an uninterrupted recovery. On the third day $l$ stopped the iodoform, and on the fourth removed the tube. There was no trouble with the wound, and recovery was perfect.

When iodoform is insufflated into the trachea, the cilia of the epithelium on the mucous membrane carry the 
particles of iodoform upwards as far as the larynx, when they are expectorated with the mucus through the tracheotomy tube. I found that the best time to insufflate was just after the act of expiration.

Walterton-road, W.

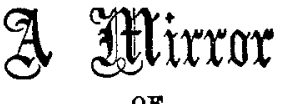

\section{HOSPITAL PRACTICE, BRITISH AND FOREIGN.}

Nulla autem est alia pro certo noscendi via, nisi quamplurimas et morborum et dissectionum historias, tum aliorum tum proprias collectas inabere, et inter se comparare.-MorgagNI De Sed. et Caus. Morb., lib. iv. Procmium.

\section{LONDON HOSPITAL.}

TWO CASES OF FOREIGN BODY REMOVED FROM THE FEMALE BLADDER; OVARIOTOMY FOR THE SECOND TIME; RECOVERY.

(Under the care of Mr. Rrvingron.)

THE variety of foreign bodies introduced into the female bladder is large-in fact, the majority of calculi in the adult female are formed round some substance which has been introduced into the bladder by the patient. $A$ s a rule it is easy to detect and remove them through the urethra, with or without crushing, but occasionally, from the shape of the substance, it is necessary to remove them by vaginal or supra-pubic operation. In the first case it was necessary to perform the former operation, for the hair-pin had transfixed the bladder, and was immovable from the urethra. The third case, that of successful ovariotomy for a second. time, is interesting from the fact that such operations are uncommon, it being a rare occurrence for the ovary left in a healthy condition at the first operation to become diseased.

Case 1. Calculus in the Bladder of a Female formed round, a IIair-pin; Vaginal Lithotomy; Cure.-Lavinia C-_, aged twenty-two, single, was admitted on Nov. 27th, 1885. She complained of incontinence of urine, which had lasted for seven months. On examination, one end of an ordinary but rusted hair-pin was found protruding through the anterior 'wall of the vagina nearly in the middle line, whilst the other was found protruding rather higher up and to the right. Examination of the bladder with the sound showed that the pin was covered with a considerable incrustation of phosphates. The patient would not admit that she had introduced the hair-pin herself, but stated that eight months previously she had been out with a young man, and that afterwards incontinence came on, and she felt something pricking her. Under an anæsthetic an incision was made through the lower and central aperture caused by the protrusion of the hair-pin through the anterior vaginal wall, and the other limb of the hair-pin was pushed back into the bladder. The two limbs were then pressed together, and the whole mass was withdrawn through the veginal wound. The opening was sewn up, and a catheter was not retained. The stitches were removed on Dec. $22 \mathrm{nd}$, when it was found that the wound had closed, a small opening, representing the ulcerated aperture caused by the hair-pin, alone remaining. This was refreshed with the nitrate-of-silver stick and closed in a few weeks.

CASE 2. Pen-holder in Female Bladder; Removal per Urethram; Cure.-A. H-, aged eighteen, tie-maker, was admitted on Feb. 12th, 1886, suffering from pain and incontinence. It was stated that a pen-holder had accidentally entered the bladder whilst the patient was sitting down on a chair. On Feb. 16th the patient was anæsthetised and placed in the lirhotomy position. The sound detected a hard body. The urethra was dilated with the index finger, which encountered the body lying across the bladder transversely to the urethral axis and firmly fixed. Six ounces of warm water having been injected, the pen-holder was shifted from its transverse position by means of the sound and was then seized with forceps and brought into the urethra. Here the nib of the pen caught in a fold of mucous membrane, which had to be nipped across before the pen-holder could be extracted. The instrument was found to be $3.1 \mathrm{in.}$ long and was made up of a bone-handled stiletto used in ladies' fancy work, over which a barrel pen nib had been placed. It was partly encrusted with earthy phosphates. After the operation, the urine, which had been thick with pus and mucus, and was alkaline, gradually cleared and became normal, the incontinence ceased, and the patient was discharged on Feb. 25th.

Case 3. Ovariotomy for a second time; Recovery.S. B- aged forty-three, married, was admitted under Dr. Down on Nov. 11th, 1885. Three years before she had had an ovarian tumour removed by Mr. James E. Adams, and had made a good recovery. Her abdomen was distended with ascitic fluid, and she suffered severe pain in her chest, abdomen, sides, and back; she hardly ever slept on account of the pain. Tongue furred and moist; no appetite; bowels regular; temperature normal; pulse 100 ; respiration 40 ; dyspnoea; circumference at umbilicus 36 in.; urine acid and free from albumen and sugar.

Nov. 14th.--Tapped; 340 ounces of fluid removed, with much relief.

18th. - Great pain in left leg and thigh; œdematous; superficial veins congested; phlebitis of femoral and saphenous veins.

Dec. 4th.--Tapped to 340 ounces. A firm lobulated tumour could then be felt in the right iliac and lumbar regions.

18th.-Ascites increased. Tapped to 335 ounces. Tumour distinct.

Jan. 7th.-Patient in a very critical state, with vomiting and retching. Pulse feeble; expression anxious. Tapped to 25 ounces, with relief.

8th.-Transferred to surgical side for immediate operation, which was performed under the spray. An incision three inches in length proved sufficient for the removal of the tumour after the evacuation of a large quantity of bloodstained ascitic fluid. The tumour itself was as large as a good-sized cocoa-nut, multilocular, and containing one large and three small cysts, of which one was bilocular. The large cyst was smooth outside, but inside was nearly filled up with a nodular papillomatous growth springing from the whole of the inner surface. The small cysts contained similar growths, and in one the growth had burst through the cyst wall and was fungating without any corering. The fungating mass was extremely vascular, and bled on the slightest touch. The growth was contained in the right broad ligament, and the ovary was not distinguishable. The stump of the former pedicle on the left side was examined, and found to be free from disease. The abdominal wall was extremely thin and the patient much reduced at the time of the operation. She recovered without a bad symptom. The temperature did not rise above normal. The wound was dressed for the first time at the end of a week, and was then nearly closed. The patient was discharged well on Feb. 25th.

\section{EDINBURGH ROYAL INFIRMARY.}

A CASE OF REMOVAL OF THE ENTIRE LOWER JAW BY THE MOUTH FOR ACUTE NECROSIS; REMARKS.

(Under the care of Prof. Annandale.)

WE are indebted to Mr. Reginald E. Horsley, M.B., C.M., house-surgeon, for the following notes (by permission of Professor Annandale).

H. H-, aged seven, was admitted on Nov. 16th, 1885 , suffering from great swelling of the face, and suppuration in connexion with the lower jaw. With the exception of an attack of croup and measles, the latter two years ago, the patient had enjoyed excellent health up to the date of the present attack, which began about ten days previous to admission, the child being at the time apparentiy in the soundest health. The family history is in every sense good, nor is there any record on either side of scrofula or sypulilis. The present attack commenced with acute pain in the region of the last molar tooth on the right side of the lower jawi.e., the second molar of the first dentition, which, in common with its fellow of the opposite side, was carious. On Saturday, Nov. 7 th, swelling in the region of the tooth mentioned was observed by the father, and two days later the patient, being seized with a rigor and suffering intense pain, became so feverish that he was obliged to remsin in bed. On this day the swelling in the gum was noticed to have increased, and three days later burst into the mouth, discharging much pus. Next day, the patient's condition becoming more and more serious, a medical man was called 